\title{
ANALYSIS OF CAUSING FACTORS ON THE APPEARANCE OF HABS IN COASTAL WATER OF MAKASSAR
}

\author{
Rahmadi Tambaru ${ }^{1 *}$, Yayu A. La Nafie ${ }^{1}$, Astrid W. Junaidi ${ }^{1}$ \\ Submitted: July 25, 2018,. Accepted: August 27, 2018
}

\begin{abstract}
HABs were types of phytoplankton considered dangerous in the sea. Its appearance was triggered by an increase in nutrients and the presence of physical and chemical factors in the optimal conditions to support its growth. For that reason, research on the analysis of the causes of the emergence of HABs in the coastal waters of Makassar has been carried out. The implementation is carried out from March to June 2017 using non-experimental methods. The results showed that there were seven types of HABs, such as Protoperidinium, Gymnodinium, Ceratium, Prorocentrum, Gyrodinium, Gonyaulax, and Dinophysis. That types from the Dinophyceae Class. The appearance of the types of HABs was due to the influence of temperature with the relationship were very strong and positive.
\end{abstract}

Keywords: Phytoplankton, HABs, Makassar, Coastal, Temperatu

\section{INTRODUCTION}

Increased abundance of various types of phytoplankton is a natural phenomenon. The effect of the increase does not always have a detrimental effect if the growth is healthy, and the environment is not disturbed (Irawan et al., 2014). If the increase is genera that produce toxins/poisons, that needs to be anticipated. This is often termed HABs (Harmful Algae Blooms) (Panggabean, 2006).

In line with developments in the science of plankton, the genus of phytoplankton which developed very rapidly but did not produce toxins/poisons turned out to also be categorized as HABs. This can disrupt the stability of the marine ecosystem because it causes oxygen depletion if you experience death simultaneously.

Rapid phytoplankton abundance of types of HABs can occur because the waters support growth (algae bloom). It can have an impact on the lives of other organisms. Some of the impacts that can occur are that fish can experience death, contaminated sea food, poisoning (health problems in the community), and community structures in the ecosystem are changing (Núñez et al., 2011; Risamasu et al., 2011; Carmichael, 2013).

Indonesia coastal and sea waters, HABs are found in about 30 genera (Praseno and Sugestiningsih, 2000). Its presence should be watched out. One factor that triggers its appearance is due to nutrient enrichment in the waters. This happens because of supply from land and air (including rainfall) (Hasani et al., 2012 and Karydis, 2009). Upwelling events are also another factor (Dale and Reid, 2006). Besides that, its appearance can also be triggered because the physicalchemical factors (temperature, salinity, and $\mathrm{pH}$ ) are optimum and support their growth. In this regard, Dale and Reid (2006) explain that a combination of

Corresponding author:

Rahmadi Tambaru ${ }^{*}$

Email: aditbr69@yahoo.com

${ }^{1}$ Departemen Ilmu Kelautan, Universitas Hasanuddin biological, physical, and chemical processes can cause HABs to be present in the sea.

Research on HABs is necessary for water. This is intended to be part of the early warning system if the abundance increases. One of the research locations is the coastal waters of Makassar City. For a long time, the waters have been used as fishing grounds. In these waters, information about $\mathrm{HABs}$ is not found, including search through literature. For this reason, research on the analysis of causing factors on the appearance of $\mathrm{HABs}$ has been carried out in these waters.

\section{MATERIAL AND METHODS}

This research was conducted in March - June 2017 in coastal and sea waters of the Makassar city. The study used non-experimental methods. Location of research is three stations. The station I is at Losari Beach Makassar, Station II is around POPSA Makassar, Station III is part of the waters of Lae-Lae Island (Figure 1). The research was carried out in the period between 10.00-14.00 WITA.

Each station carried out water sampling for enumerating genus HABs. To identify it using an identification book from Tomas (1997), Newell and Newell (1977), and Yamaji (1960). Furthermore, physical and chemical factors such as temperature, salinity, and $\mathrm{pH}$ are measured. These factors are key parameters for phytoplankton growth. To measure the concentration of nitrates and orthophosphates, 1 liter of seawater was taken, then analyzed in the Oceanographic Chemistry Laboratory of the Department of Marine Sciences FIKP-Unhas.

The measurement results for physical and chemical factors, then analyzed descriptively to see the distribution of each at various stations. To examine the distribution of HABs, the One way ANOVA analysis is carried out based on the station. To analyze the relationship between genera HABs and physical and chemical factors, Pearson's Correlation analysis $(\mathrm{p}=$ 0.05 ) was carried out. 


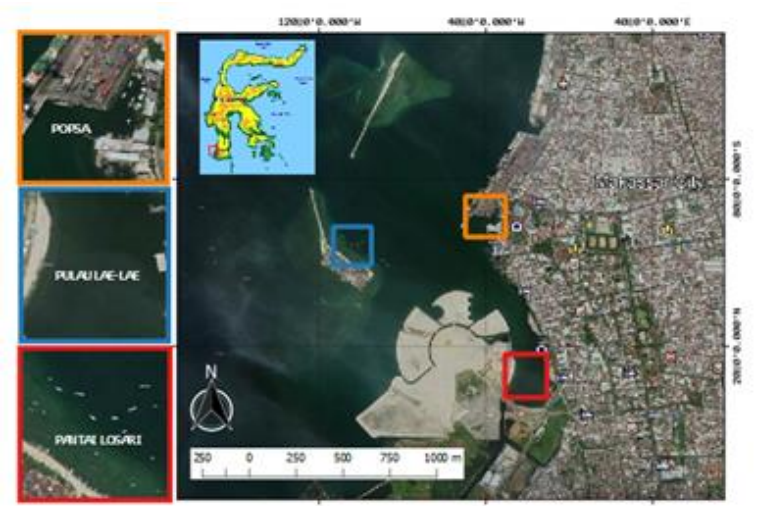

Figure 1. Research Location

Through this analysis, several physical and chemical factors will be found as factors that trigger the presence of HABs in the waters.

\section{RESULTS AND DISCUSSION}

\section{Physics and Chemistry Factors}

The purpose of the measurement of physical and chemical factors in this study is to determine its availability in supporting the life of phytoplankton. It is possible that among these factors is the trigger for the emergence of HABs. For that, the following explanation :

\section{Temperature}

Based on the measurement results, temperatures range between $31-34 \mathrm{oC}$ (Figure 2). The average temperature in each Station I, II, and III is $34{ }^{\circ} \mathrm{C}, 33{ }^{\circ} \mathrm{C}$, and $32{ }^{\circ} \mathrm{C}$. The temperature range is still within the range of values that support the growth of phytoplankton. Effendi (2000) explained that several phytoplankton genera (genus in the Bacillariophyceae and Chlorophyceae class) still grow well to $35^{\circ} \mathrm{C}$. This means that temperature is one of the key parameters in supporting the growth of phytoplankton in the waters.

Furthermore, the composition and size of phytoplankton are strongly influenced by the presence of temperature distribution at sea (Ayadi et al., 2004).

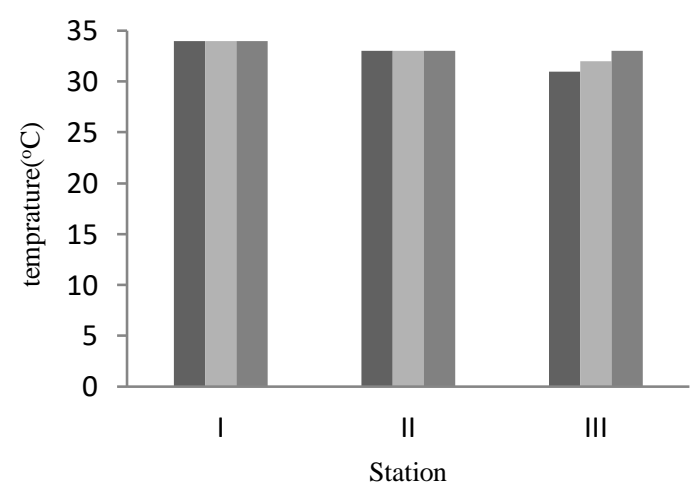

Figure 2. Temperature Measurement Results $\left({ }^{\circ} \mathrm{C}\right)$

Temperature can act as one of the determinants of the succession of phytoplankton genus in the waters.

\section{Salinity}

The results of salinity measurements ranged from 25 26 ppt (Figure 3). The average values of Stations I, II, and III are $26 \mathrm{ppt}, 26 \mathrm{ppt}$, and $25 \mathrm{ppt}$. The range of salinity values is still as needed for phytoplankton. The salinity range between $10-40 \mathrm{ppt}$ is the optimum range for growth (Raymont, 1980). To note, salinity is one of the key parameters that affect the production of phytoplankton (Barron et al. 2002). According to Ayadi et al. (2004), salinity is one of the environmental factors that can change the community structure of phytoplankton (Ayadi et al. 2004).

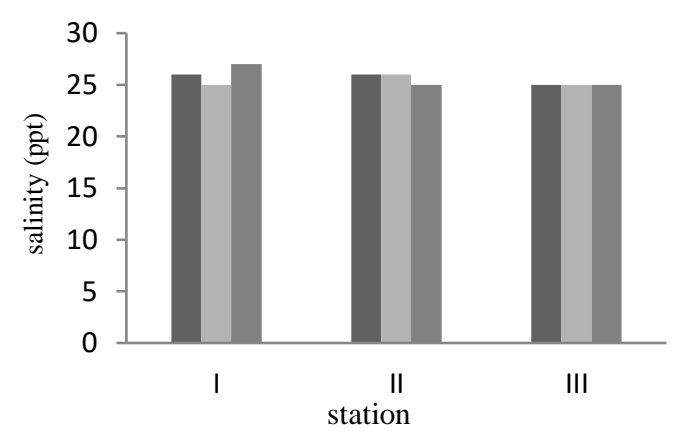

Figure 3. Salinity Measurement Results

\section{Degree of Acidity $(\mathrm{pH})$}

The measurement results for $\mathrm{pH}$ are in the range of 7.21 - 7.23 (Figure 4) with the average values of Stations I, II, and III are 7.23, 7.21, and 7.21. Based on this, the $\mathrm{pH}$ value is considered the same at all stations. The range of values is still in the range that is by the growth of phytoplankton. This means that the effect on the growth of phytoplankton is considered normal. According to Syamsuddin (2014), the $\mathrm{pH}$ value between $6.5-8.0$ is the ideal range to support the growth of phytoplankton.

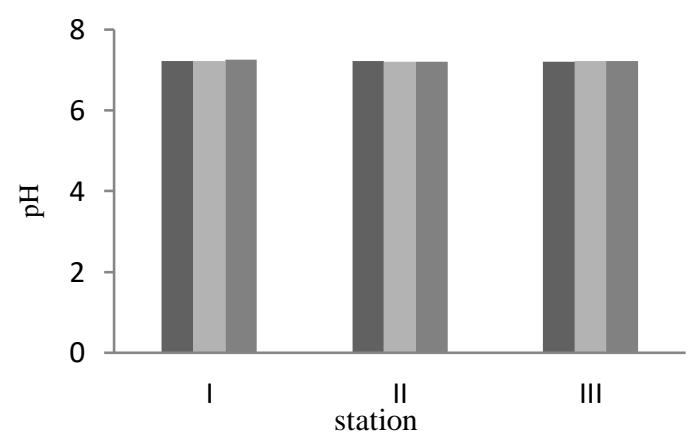

Figure 4. Acidity (pH) Measurement Results

\section{Nitrate}

During the study, nitrate concentrations ranged from 0.02-0.07 mg/L (Figure 5). The average concentration of nitrates in Stations I, II, and III is $0.05 \mathrm{mg} / \mathrm{L}, 0.02$ $\mathrm{mg} / \mathrm{L}$, and $0.06 \mathrm{mg} / \mathrm{L}$. Associated with water fertility categories, the coastal waters of Makassar City fall into the low category. This means that the concentration of Nitrate has not affected the growth of phytoplankton 
quickly and densely. Nitrates have a very strong effect if the concentration is more than $0.2 \mathrm{mg} / \mathrm{L}$ (Effendi, 2000).

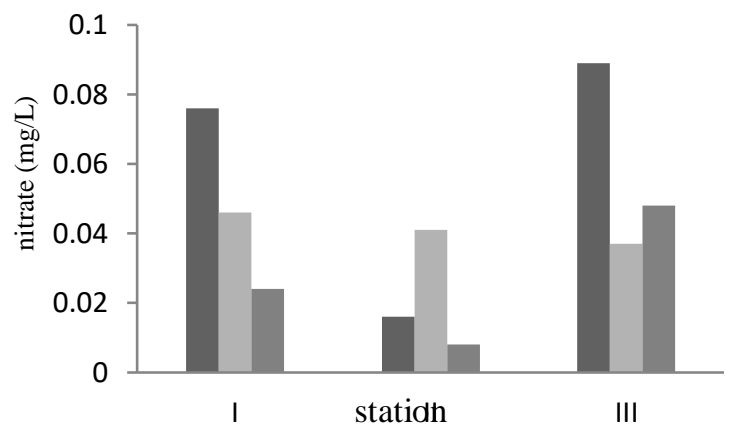

Figure 5. Nitrate Measurement Results (mg/L)

\section{Orthophosphate}

Orthophosphate is one of the nutrients that determine water fertility. Together with nitrates, these two types of nutrients are materials that are needed by phytoplankton to grow. Based on the results of measurements, orthophosphate concentrations ranged from $0.002-0.020 \mathrm{mg} / \mathrm{L}$ (Figure 6). The average value in Stations I, II, and III is $0.002 \mathrm{mg} / \mathrm{L}, 0.020 \mathrm{mg} / \mathrm{L}$, and $0.008 \mathrm{mg} / \mathrm{L}$. Orthophosphate concentrations based on stations are different and tend to be low. According to Effendi (2000), waters which have a range of orthophosphates between $0,000-0,020 \mathrm{mg} / \mathrm{L}$ are waters that have low fertility.

\section{Distribution of HABs}

There were seven genera of HABs found during the study. The genera are Protoperidinium, Gymnodinium, Ceratium, Prorocentrum, Gyrodinium, Gonyaulax, and Dinophysis. They are genera of the Dinophyceae class (Wiadnyana, 1996). Based on their distribution, there were seven genera of HABs found at Station I namely

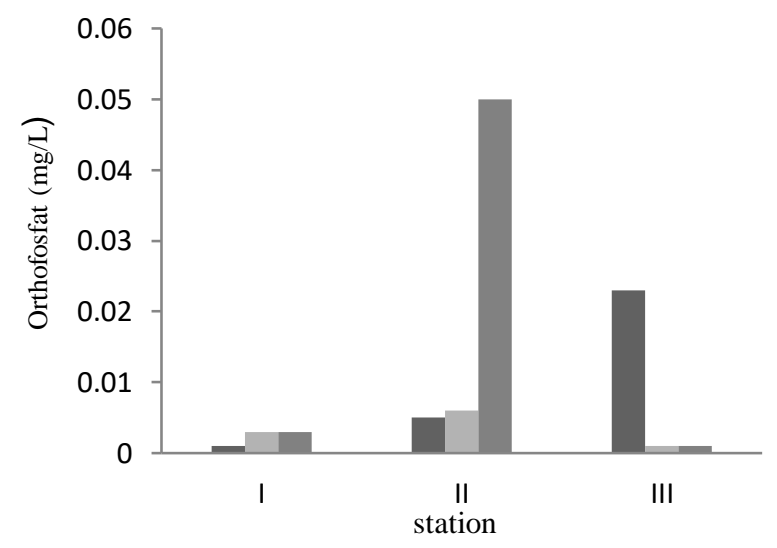

Figure 6. Orthophosphate Measurement Results (mg/L)

Protoperidinium, Gymnodinium, Ceratium, Prorocentrum, Gyrodinium, Gonyaulax, and Dinophysis, at Station II found five genera Protoperidinium, Gymnodinium, Ceratium, Prorocentrum, and Gonyaulax, and Station III also detected five genera namely Protoperidinium, Gymnodinium, Ceratium, Gonyaulax, and Dinophysis.

Furthermore, the abundance of HABs based on stations can be seen in Figure 8. The abundance of HABs at Station I ranges from 135-648 cells / 1, Station II ranges from 268-395 cells / 1, and Station III 28-235 cells / 1. In the picture, it can be seen that the abundance of HABs is different based on the station. After testing based on the One Way ANOVA Test, it turned out that the abundance of HABs was not significantly different ( $p>0.05$ ). This shows that the abundance of HABs is considered the same at all research stations.

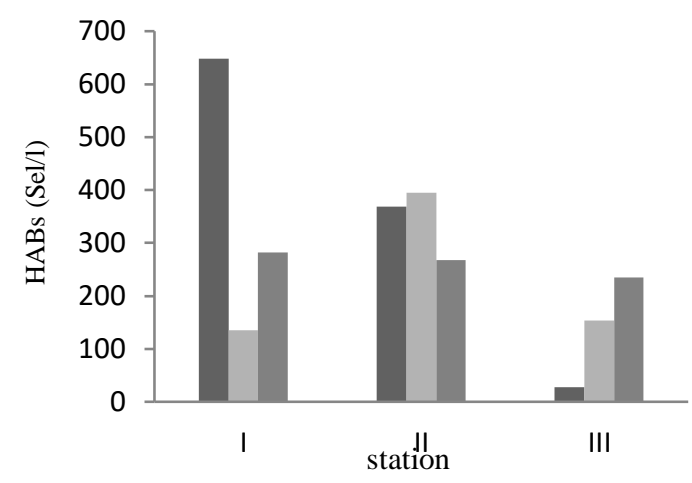

Figure 7. Enumeration Results of Abundance of HABs

There are four genera of seven genera HABs that always appear at all stations. The genus in question is Protoperidinium, Gymnodinium, Ceratium, and Gonyaulax. The appearance of the four genera is a phenomenon when compared to other genera. However, when viewed from their ability to develop, their presence can be considered reasonable. The four can accumulate nutrients from low to high concentrations (Sidabutar, 2006). In a study conducted in Kamal Muara North Jakarta, the four genera were also found (Mulyani et al., 2012).

The dominance of genus HABs can occur if the nutrients and physical-chemical factors of the waters are in optimum conditions to support their growth. According to Livingston (2001), the phytoplankton, including genus HABs, can become dominant when the types of nutrients are in very high concentrations. During the event, the genera in the Dinophyceae class can be triggered to produce toxins/poisons that are thrown into the waters. The presence of these toxins/poisons can be an obstacle to the growth of genera to other phytoplankton classes.

The above incident has not occurred in the coastal waters of Makassar City. The concentration of nutrient types is still low (see the explanation for Figure 5 and Figure 6). The abundance of the four genera of HABs such as Protoperidinium, Gymnodinium, Ceratium, and Gonyaulax has also not been categorized very abundantly (algae bloom) because it has not reached> 106 cells / L (Sidabutar, 2006). However, it should be watched out because the genera of HABs have begun to appear and develop. 


\section{Connectivity between HABs and Factors of Physics-Chemistry in Waters}

Physical and chemical factors such as temperature, salinity, $\mathrm{pH}$, nitrate, and orthophosphate are factors that significantly influence phytoplankton activity, including the genera HABs (Wells, at al., 2015). The abundance of genera HABs is changing because of the influence of changes in physical-chemical factors in the waters.

The relationship of various physical-chemical factors in triggering the emergence of HABs in coastal waters of Makassar City was analyzed using Pearson Correlation $(p=0.05)$. Based on the results of the analysis, the temperature has a strong relationship with the appearance of HABs $(p<0.05)$. The strength of the relationship was very strong $(76.6 \%)$ and positive. This means that the appearance of HABs is triggered by temperatures in the coastal waters of Makassar City. Salinity, $\mathrm{pH}$, nitrate, and orthophosphate were considered not to show a significant relationship ( $p>$ $0.05)$.

Ecologically, the temperature is an environmental factor that influences the presence of various aquatic organisms, including HABs. According to Boumen et al. (2003) and Ayadi et al. (2004), the temperature affects the changes in phytoplankton composition. For the case in the coastal waters of the Makassar city, that might happen. Some genera of HABs that appear are the result of the intended effect. In this study, the temperature range can still be tolerated by phytoplankton including HABs for growth and development (ranging from $31-34 \mathrm{oC}$ ) even though it is outside the maximum range for growth (20-30oC) (Syamsuddin, 2014).

\section{CONCLUSION}

The genera of HABs identified are Protoperidinium, Gymnodinium, Ceratium, Prorocentrum, Gyrodinium, Gonyaulax, and Dinophysis. They are a group from the Dinophyceae Class.

Temperature is a trigger factor for the appearance of HABs. The strength of the relationship is very strong and positive.

\section{REFERENCES}

Ayadi, H., O. Abid, J. Elloumi, A. Bouain \& T. SimeNgando. 2004. Structure of the phytoplankton communities in two lagoons of different salinity in the Sfax Salters (Tunisia). Journal of Plankton Research. Vol 26(6): 669-679.

Barron, S., C. Weber, R. Marino, E. Davidson, G. Tomasky \& Robert Howarth. 2002. Effects of varying salinity on phytoplankton growth in a low-salinity coastal pond under two nutrient conditions. Biological Bulletin. 203: 260-261.
Bouman, H. A., T. Platt, S. Sathyendranath, W. K. W. Li, V. Stuart, C. Fuentes-Yaco, H. Maass, E. P. W. Horne, O. Ulloa, V. Lutz \& M. Kyewalyanga. 2003. Temperature as an indicator of optical properties and community structure of marine phytoplankton: implications for remote sensing. Marine Ecological Program Series. Vol. 258: 19-30.

Carmichael, W.W., 2013. Human health effects from harmful algal blooms: a synthesis. Submitted by the $H P A B$ to the International Joint Commission. Department of Biological Sciences, Wright State University.

Dale, B. Edwards, M. Reid \& P.C. 2006. Ecology of harmful algae: climate change and harmful algal bloom. Springer-Verlag. Heidelberg.

Effendi, H. 2000. Telaah kualitas air (bagi pengelolaan sumberdaya dan lingkungan perairan). Yogyakarta.

Hasani, Q., E.M. Adiwilaga \& N.T. Murti. 2012. The relationship between the harmful algal blooms (habs) phenomenon with nutrients at shrimp farms and fish cage culture sites in pesawaran district Lampung Bay. Makara Journal of Science. Vol 16/3: 183-191.

Irawan, A., Q. Hasani \& H. Yuliyanto. 2014. Fenomena harmful algal blooms (habs) di pantai ringgung teluk lampung, pengaruhnya dengan tingkat kematian ikan yang dibudidayakan pada karamba jaring apung. Jurnal Penelitian Pertanian Terapan. Vol 15 (1) : 48-53.

Karydis, M., 2009. Eutrophication assessment of coastal waters based on indicators: a literature review. Global NEST Journal. Vol 11(4) : 373390.Livingston, R.J., 2001. Eutrophication processes in coastal systems. CRC Press.

Mulyani, R. Widiarti \& W.Wardhana. 2012. Sebaran spasial spesies penyebab harmful algal bloom (hab) di lokasi budidaya Kerang Hijau (Perna Viridis) Kamal Muara Jakarta Utara. Jurnal Akuatika. Vol. III (1) : 28-39.

Newell, G.E. \& R.C. Newell. 1977. Marine plankton a practical guide. Hutchison.

Núñez, E.J., I.Gárate, C.J. Band, A. Cordero; D.J. Lopez, F.E. Hernandez, A. Heredia \& J.J. Bustillos. 2011. Impact of harmful algal blooms on wild and cultured animals in the Gulf of California. Journal of Environmental Biology, 32: 413-423.

Panggabean, L. 2006. Kista dinoflagellata penyebab HAB. Oseana, 31(2): 11-18. 
Praseno, D. P. \& Sugestiningsih. 2000. Retaid di perairan Indonesia. Pusat Penelitian dan Pengembangan Oseanologi-LIPI, Jakarta: 82 hal.

Raymont, J.E.G., 1980. Plankton and productivity in the ocean. Pergamon Press. Oxford.

Risamasu, F.J.L \& H. B. Prayitno. 2011. Kajian zat hara fosfat, nitrit, nitrat dan silikat di perairan Kepulauan Matasiri Kalimantan Selatan. Ilmu Kelautan. 16 (3): 135-142.

Sidabutar, T. 2006. Bencana akuatik di perairan Teluk Jakarta tragedi bulan Mei 2004. Prosiding Seminar Nasional Tahunan III Hasil-hasil Penelitian Perikanan dan Kelautan, Fakultas Pertanian, UGM, Yogyakarta.

Syamsuddin, R,. 2014. Pengelolaan kualitas air: teori dan aplikasi di sektor perikanan. Pijar Press. Makassar.
Tomas, C.R, 1997. Identifying marine phytoplankton. Academic Press. America.

Wells, M.L., V.L. Trainer, T.J. Smayda, B.S.O. Karlson, C.G. Trick, R.M. Kudela, A. Ishikawa, S.Bernard, A.Wulff, D.M. Anderson \& W.P. Cochlan. 2015. Harmful algal blooms and climate change: learning from the past and present to forecast the future. Harmful Algae. Elsevier. 49: 68-93.

Wiadnyana, N. 1996. Mikroalga berbahaya di perairan Indonesia. Oseanologi dan Limnologi di Indonesia, 29: 15-28.

Yamaji, 1960. Identification of marine plankton. Ilustsation Of Marine Plankton Of Japan. Japan. Hoikusha publishing co. Ltd. Osaka. Japan. 